\title{
Methyltrioctylammonium chloride catalysed sonochemical synthesis of acridine diones
}

\author{
BHUPINDER KAUR and HARISH KUMAR* \\ Department of Chemistry, Sant Longowal Institute of Engineering and Technology, Longowal 148 106, India \\ e-mail: choprahk67@gmail.com
}

MS received 21 May 2012; revised 30 January 2013; accepted 1 March 2013

\begin{abstract}
The greener, clean and efficient protocol for the synthesis of acridine diones derivatives has been achieved by reacting aromatic aldehyde, dimedone and amines using methyltrioctylammonium chloride (Aliquate 336) as a catalyst under ultrasonic irradiations.
\end{abstract}

Keywords. Ultrasound irradiation; methyltrioctylammonium chloride; acridine diones derivatives.

\section{Introduction}

Ultrasound irradiation in organic synthesis is considered as a clean and energy conserving protocol as compared to the traditional methods and has been established as a versatile technique in synthetic organic chemistry. ${ }^{1-4}$ It has been well established that ultrasound, when compared with conventional methods enhance the rate of reactions and product yields in addition to sometimes changing the reaction pathway. ${ }^{5,6} \mathrm{In}$ recent years, acridine diones have attracted keen interest of the researchers because of their use as drugs for cardiovascular diseases, such as angina pectoris, ${ }^{7}$ hypertension, ${ }^{8}$ antitumour agents, ${ }^{9-11}$ DNA-binding moieties and DNA-intercalating anticancer drugs. ${ }^{12,13}$ Therefore, the synthesis of acridine diones derivatives is an important and principal task in organic chemistry. A straightforward method for the synthesis of these compounds involve a condensation between aldehydes, dimedone and amines that is catalysed by various compounds such as poly-phosphoric acid ${ }^{14}$ (cetyltrimethylammonium bromide CTAB), ${ }^{15}$ L-proline, ${ }^{16}$ zeolite,${ }^{17}$ $\mathrm{N}$-propyl sulphamic acid, ${ }^{18}$ ionic liquids, ${ }^{19}$ microwave irradiations. ${ }^{20}$ They often suffer from the draw backs of long reaction times, harsh reaction conditions, toxicity, and difficulty in product separation, which limits its uses in the synthesis of complex molecules. Ionic liquids have attracted extensive research interest in recent years as environmentally benign solvents due to their favourable properties like non-inflammability, negligible vapour pressure, reusability and high thermal stability. ${ }^{21,22}$ Combining these unique properties of ionic liquids they are emerging as a 'green reaction media'

*For correspondence (catalyst + solvent). The use of ionic liquids as reaction medium may offer a convenient solution to both the solvent emission and catalytic recycling problem. ${ }^{23-25}$

To the best of our knowledge, acridine diones derivatives involving catalytic amount of ionic liquid methyltrioctylammonium chloride (Aliquate 336) under ultrasonication is unprecedented. In continuation of our interest in developing novel synthetic methodologies and use of ionic liquid as catalyst under ultrasonic irradiation for organic synthesis, ${ }^{26-28}$ here, we have developed methodology for the synthesis of acridine diones derivatives in the presence of methyltrioctylammonium chloride under ultrasonication.

\section{Experimental}

\subsection{General}

All melting points were recorded in open capillary measurements, using sulphuric acid bath and are uncorrected. IR spectra were recorded as $\mathrm{KBr}$ pellets on a Perkin-Elmer spectrophotometer. NMR spectra were recorded on AL-300F (Bruker) FT NMR spectrophotometer using $\mathrm{CDCl}_{3}$ as internal standard. Sonication was performed in ELMA, Transonic T 310/H Ultrasonic cleaner (with a frequency of $40 \mathrm{KHz}$ ), Hans Schmidbauer GmbH and Co., Germany. The reactions were performed in open vessels.

\subsection{General procedure for the synthesis of acridine diones derivatives}

In a beaker a mixture of aromatic aldehyde ( $1 \mathrm{mmol})$, dimedone (2 mmol), ammonium acetate/aromatic 


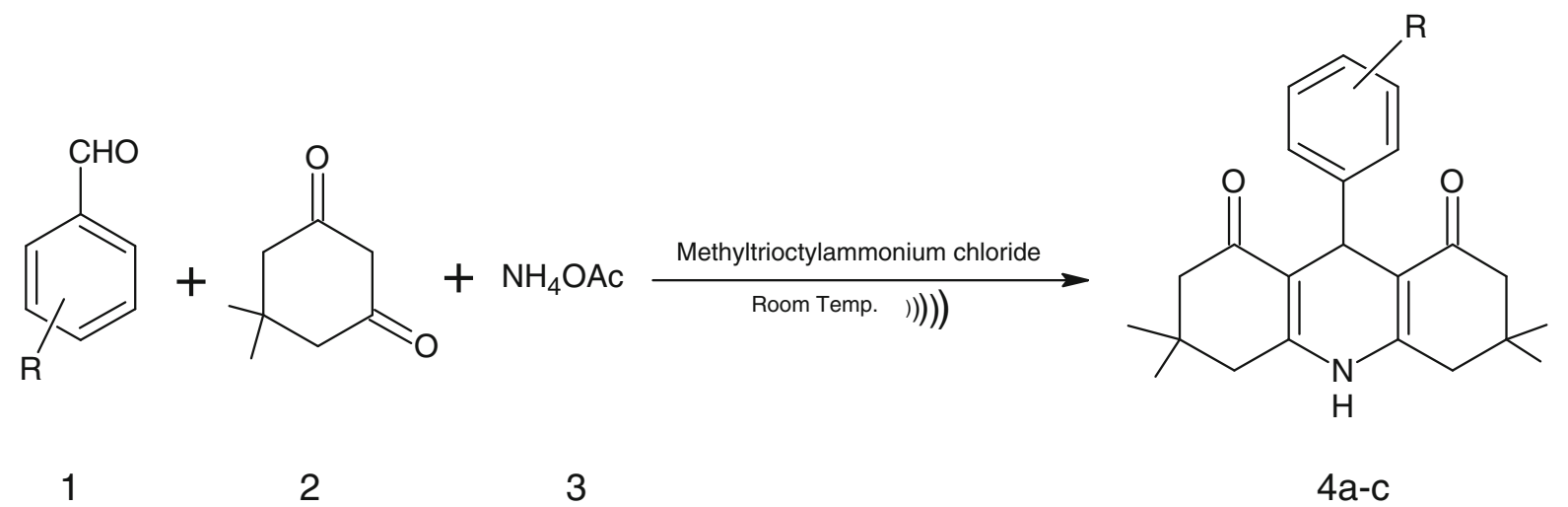

Scheme 1. Synthesis of tetrahydroacridine-1,8 (2H,5H,9H,10H)-diones.

amine $(1+)$ was mixed with methyltrioctylammonium chloride $(10 \mathrm{~mol} \%)$ (schemes 1 and 2$)$ which was irradiated under ultrasonic waves at the room temperature for an appropriate time (see table 2). The progress of the reaction was monitored by TLC. After the completion of reaction the solid product was filtered. This solid product was recrystallized from ethanol.

2.2a 3,3,6,6-Tetramethyl-9-(3-nitrophenyl)-3,4,6,7tetrahydroacridine- $1,8(2 \mathrm{H}, 5 \mathrm{H}, 9 \mathrm{H}, 10 \mathrm{H})$-dione $(\mathbf{4 a})$ : mp 273-275 ${ }^{\circ}$; ${ }^{1} \mathrm{H}-\mathrm{NMR}\left(\mathrm{CDCl}_{3}\right) \delta 0.89(\mathrm{~s}, 6 \mathrm{H}), 1.03$ $(\mathrm{s}, 6 \mathrm{H}), 2.0(\mathrm{~d}, J=16.3 \mathrm{~Hz}, 2 \mathrm{H}), 2.15(\mathrm{~d}, J=16.3 \mathrm{~Hz}$, $2 \mathrm{H}), 2.28(\mathrm{~d}, J=17.1 \mathrm{~Hz}, 2 \mathrm{H}), 2.38(\mathrm{~d}, J=17.1 \mathrm{~Hz}$, $2 \mathrm{H}), 5.01(\mathrm{~s}, 1 \mathrm{H}), 7.30(\mathrm{t}, J=7.86 \mathrm{~Hz}, 1 \mathrm{H}), 7.60(\mathrm{~d}$, $J=6.9 \mathrm{~Hz}, 1 \mathrm{H}), 7.85(\mathrm{~d}, J=8.1 \mathrm{~Hz}, 1 \mathrm{H}), 8.02(\mathrm{~s}$, $1 \mathrm{H}), 8.90$ (s, br., $1 \mathrm{H}) ;{ }^{13} \mathrm{C}-\mathrm{NMR}\left(\mathrm{CDCl}_{3}\right) \delta 27.4,29.9$, $32.9,34.4,51.1,112.2,121.2,123.1,130.0,135.2$, 148.4, 149.6, 150.2, 195.6; IR $\left(\mathrm{cm}^{-1}\right)$ 3380, 3060, 2960, 1645, 1610, 1520, 1480, 1360, 1340, 1220, 1140.
$2.2 \mathrm{~b}$ 3,3,6,6-Tetramethyl-9-(4-nitrophenyl)-3,4,6,7tetrahydroacridine- $1,8(2 \mathrm{H}, 5 \mathrm{H}, 9 \mathrm{H}, 10 \mathrm{H})$-dione $(\mathbf{4 b})$ : mp $282-283^{\circ} \mathrm{C} ;{ }^{1} \mathrm{H}-\mathrm{NMR}\left(\mathrm{CDCl}_{3}\right) \delta 0.87(\mathrm{~s}, 6 \mathrm{H})$, $1.05(\mathrm{~s}, 6 \mathrm{H}), 2.08(\mathrm{~d}, J=16.3 \mathrm{~Hz}, 2 \mathrm{H}), 2.18(\mathrm{~d}$, $J=16.3 \mathrm{~Hz}, 2 \mathrm{H}), 2.24(\mathrm{~d}, J=17.0 \mathrm{~Hz}, 2 \mathrm{H}), 2.38(\mathrm{~d}$, $J=17.0 \mathrm{~Hz}, 2 \mathrm{H}), 5.08(\mathrm{~s}, 1 \mathrm{H}), 7.46(\mathrm{~d}, J=8.5 \mathrm{~Hz}$, $2 \mathrm{H}), 7.98(\mathrm{~d}, J=6.9 \mathrm{~Hz}, 2 \mathrm{H}), 8.47(\mathrm{~s}, 1 \mathrm{H}) ;{ }^{13} \mathrm{C}-\mathrm{NMR}$ $\left(\mathrm{CDCl}_{3}\right) \delta 27.4,29.9,32.9,34.9,51.0,112.3,123.5$, 129.4, 146.3, 149.8, 154.9, 195.6; IR $\left(\mathrm{cm}^{-1}\right) 3384$, 3070, 2956, 1643, 1515, 1479, 1342, 1218, 1166.

2.2c 3,3,6,6-Tetramethyl-9-(2-chlorophenyl)-3,4,6,7tetrahydroacridine-1,8(2H,5H,9H,10H)-dione $\quad(\mathbf{4 c})$ : mp $217-219^{\circ} \mathrm{C} ;{ }^{1} \mathrm{H}-\mathrm{NMR}\left(\mathrm{CDCl}_{3}\right) \delta 1.08(\mathrm{~s}, 6 \mathrm{H}), 1.03$ (s, 6H), 2.030-2.30 (m, 4H), 2.48-2.62 (m, 4H), 5.04 (s, 1H), $7.08(\mathrm{t}, J=7.2 \mathrm{~Hz}, 1 \mathrm{H}), 7.03-7.039(\mathrm{~m}, 1 \mathrm{H})$, $7.25(\mathrm{~d}, J=7.5 \mathrm{~Hz}, 1 \mathrm{H}), 7.47(\mathrm{~d}, J=6.4 \mathrm{~Hz}, 1 \mathrm{H})$; ${ }^{13} \mathrm{C}-\mathrm{NMR}\left(\mathrm{CDCl}_{3}\right) \delta 27.8,29.7,32.5,41.2,51.2,114.2$, 126.8, 127.6, 128.2, 130.6, 133.9, 149.4, 163.5, 197.0; IR $\left(\mathrm{cm}^{-1}\right)$ 3400, 2980,1660, 1620, 1465, 1350, 1200.<smiles>[R]c1ccc(C=O)cc1[I-]C1(C)CC(=O)CC(C)(C)C1</smiles>

$6 a-h$

Scheme 2. Synthesis of N-aryl-tetrahydroacridine-1,8 (2H,5H,9H,10H)-diones. 
Table 1. Effect of amount of catalyst with or without ultrasonication for the synthesis of acridine diones at room temperature.

\begin{tabular}{|c|c|c|c|c|c|}
\hline \multirow[b]{2}{*}{ Entry } & \multirow{2}{*}{$\begin{array}{c}\text { Aliquat } \\
336(\mathrm{~mol} \%)\end{array}$} & \multicolumn{2}{|c|}{ With sonication } & \multicolumn{2}{|c|}{ Without sonication } \\
\hline & & Yield (\%) & Time (min) & Yield (\%) & Time (min) \\
\hline 1 & 2 & Nil & 190 & Nil & 350 \\
\hline 2 & 4 & 40 & 150 & Nil & 350 \\
\hline 3 & 6 & 85 & 95 & 20 & 350 \\
\hline 4 & 8 & 89 & 85 & 22 & 350 \\
\hline 5 & 10 & 98 & 40 & 28 & 350 \\
\hline 6 & 12 & 96.5 & 50 & 30 & 350 \\
\hline
\end{tabular}

2.2d 3,3,6,6-Tetramethyl-9-(4-nitrophenyl)-10-phenyl3,4,6,7,9,10-tetrahydroacridine-1,8- $(2 \mathrm{H}, 5 \mathrm{H}, 9 \mathrm{H}, 10 \mathrm{H})$ dione (6b): $\mathrm{mp} 278-280{ }^{\circ} \mathrm{C}{ }^{1} \mathrm{H}-\mathrm{NMR}\left(\mathrm{CDCl}_{3}\right): \delta 0.75$ (s, 6H), 0.89 (s, 6H), $1.75(\mathrm{~d}, J=17.5 \mathrm{~Hz}, 2 \mathrm{H}), 2.03$ $(\mathrm{d}, J=17.5 \mathrm{~Hz}, 2 \mathrm{H}), 2.03(\mathrm{~d}, J=16.3 \mathrm{~Hz}, 2 \mathrm{H}), 2.03$ $(\mathrm{d}, J=16.3 \mathrm{~Hz}, 2 \mathrm{H}), 5.29(\mathrm{~s}, 1 \mathrm{H}), 7.03(\mathrm{~d}, J=8.2 \mathrm{~Hz}$, $2 \mathrm{H}), 7.55(\mathrm{~d}, J=8.2 \mathrm{~Hz}, 2 \mathrm{H}), 7.54(\mathrm{~s}, 1 \mathrm{H}), 7.55(\mathrm{~d}$, $J=8.8 \mathrm{~Hz}, 2 \mathrm{H}), 8.03(\mathrm{~d}, J=8.8 \mathrm{~Hz}, 2 \mathrm{H}) ;{ }^{13} \mathrm{CNMR}$ $\left(\mathrm{CDCl}_{3}\right): \delta 195.6,153.6,150.4,146.2,138.7,129.7$, $128.8,123.5,113.6,50.03,41.9,33.6,32.4,29.6,26.7$; IR $(\mathrm{KBr})\left(\mathrm{cm}^{-1}\right) 2956,1635,1594,1514,1349,1224$, 1176, 1144, 1113, 1003, 864, 830, 703, 572, 513.

\section{Results and discussion}

The optimal condition for the synthesis of acridine diones derivatives was studied. The pilot reaction was carried out using benzaldehyde, aniline and dimedone. In a typical experiment a mixture of benzaldehyde (1 mmol), aniline (1 mmol) and dimedone ( $2 \mathrm{mmol}$ ) was

Table 2. Methyltrioctylammonium chloride catalysed synthesis of acridine diones at room temperature under ultrasonication.

\begin{tabular}{lccccc}
\hline & & \multicolumn{3}{c}{ Time } & $\begin{array}{c}\text { M.pt } \\
\left({ }^{\circ} \mathrm{C}\right)^{(\mathrm{ref} .)}\end{array}$ \\
\hline $\mathbf{4 a}$ & $3-\mathrm{NO}_{2}$ & $\mathrm{NH}_{4} \mathrm{OAc}$ & 50 & 90 & $274-277^{(17)}$ \\
$\mathbf{4 b}$ & $4-\mathrm{NO}_{2}$ & $\mathrm{NH}_{4} \mathrm{OAc}$ & 40 & 93 & $283-285^{(17)}$ \\
$\mathbf{4 c}$ & $2-\mathrm{Cl}^{1}$ & $\mathrm{NH}_{4} \mathrm{OAc}$ & 35 & 94 & $215-217^{(17)}$ \\
$\mathbf{6 a}$ & $\mathrm{C}_{6} \mathrm{H}_{5}$ & $\mathrm{C}_{6} \mathrm{H}_{5}$ & 50 & 96 & $223-225^{(15)}$ \\
$\mathbf{6 b}$ & $4-\mathrm{Cl}_{1}$ & $\mathrm{C}_{6} \mathrm{H}_{5}$ & 45 & 95 & $245-248^{(15)}$ \\
$\mathbf{6 c}$ & $4-\mathrm{NO}_{2}$ & $\mathrm{C}_{6} \mathrm{H}_{5}$ & 50 & 90 & $278-280^{(15)}$ \\
$\mathbf{6 d}$ & $4-\mathrm{OCH}_{3}$ & $\mathrm{C}_{6} \mathrm{H}_{5}$ & 50 & 92 & $293-295^{(15)}$ \\
$\mathbf{6 e}$ & $\mathrm{C}_{6} \mathrm{H}_{5}$ & $4-\mathrm{CH}_{3}$ & 45 & 94 & $267-270^{(15)}$ \\
$\mathbf{6 f}$ & $4-\mathrm{NO}_{2}$ & $4-\mathrm{CH}_{3}$ & 45 & 90 & $>300^{(15)}$ \\
$\mathbf{6 g}$ & $4-\mathrm{OCH}_{3}$ & $4-\mathrm{CH}_{3}$ & 55 & 92 & $132-135^{(15)}$ \\
$\mathbf{6 h}$ & $3-\mathrm{NO}_{2}$ & $4-\mathrm{CH}_{3}$ & 55 & 93 & $279-282^{(15)}$ \\
\hline
\end{tabular}

placed under ultrasonic irradiation, at stirring and heating conditions. The results revealed that, when the reaction was carried at stirring and heating conditions it gave the lower yield of product even after prolonged reaction time. However, at the same time under ultrasonication we got the excellent yield of product in short span (table 1). The results in table 1 revealed that the ultrasonic irradiation was very simple and convenient for the synthesis of acridine diones derivatives at room temperature in the presence of ionic liquid using ultrasonic cleaner with a frequency of $40 \mathrm{KHz}$. In this experiment the ultrasonic technique represented a better procedure in terms of time and yields.

The catalytic activity of methyltrioctylammonium chloride was also studied. Methyltrioctylammonium chloride was added in varying amount. It was found that $10 \mathrm{~mol} \%$ catalysts was optimum to carry out the reaction. Using more than $10 \mathrm{~mol} \%$ of the catalyst did not affect the yield or time of the reaction to greater extent. Using less than $10 \mathrm{~mol} \%$ of the catalyst results in the less amount of the percentage yield in prolonged reaction time. To express the generality of reaction various aromatic aldehydes and amines were reacted with dimedone using methyltrioctylammonium chloride as catalyst under ultrasonic irradiation. Here, we have found that the reaction of aromatic aldehydes having electronwithdrawing and electron donating groups are equally facile for the reaction (resulting in the formation of good yield). The results obtained in the current method are illustrated in table 2 . All the products obtained were fully characterized by spectroscopic methods such as IR, ${ }^{1} \mathrm{H}$ NMR and also by comparison with the reference compounds.

\section{Conclusion}

The methodology of the synthesis of a variety of acridine diones precursors under ultrasound irradiation conditions in the presence of the catalytic amount of an 
ionic liquid, i.e., methyltrioctylammonium chloride has been developed. The present methodology gives significant advantages such as simple procedure, easy work up and clean reaction profile, use of inexpensive catalyst, excellent percentage yields, shorter reaction time, solvent free media and mild reaction conditions.

\section{Acknowledgements}

Authors are grateful to the Head, Department of Chemistry, Sant Longowal Institute of Engineering and Technology, Longowal for providing laboratory facilities.

\section{References}

1. Mason T J and Lorimer J P 1988 In Sonochemistry: Theory, application and uses of ultrasound in chemistry, New York: John Wiley and Sons

2. Suslick K S 1988 In Ultrasound its chemical physical and biological effects, Weinheim: VCH

3. Puri S, Kaur B, Parmar A and Kumar H 2009 Ultrason. Sonochem. 16707

4. Kumar H and Parmar A 2008 Ultrason. Sonochem. 15 132

5. Datta B and Pasha M A 2011 Ultrason Sonochem. 18 628

6. Luche J L 1998 Synthetic organic sonochemistry, New York: Plenum Press

7. Antman E, Muller J, Goldberg S, Macalpin R, Rubenfire M, Tabatznik B, Liang C, Heupler F, Achuff S, Reichek N, Geltmen E, Kerin N Z, Neff R K and Raunwald E 1980 N. Engl. J. Med. 3021269

8. (a) Guazzi M, Olivari M, Polese A, Fiorentini C, Margrini F and Maruzzi P 1977 Clin. Pharmacol. Ther. 22 258; (b) Hornung R S, Gould B A, Jones R I, Sonecha T N and Raferty E B 1983 Am. J. Cardiol. 511323
9. Delfourne E, Roubin C and Bastide J 2000 J. Org. Chem. 655476

10. Antonini J, Polucci P, Magnano A and Martelli S 2001 J. Med. Chem. 443329

11. Ferlin M G, Marzano C, Chiarelotto G, Baccichetti F and Bordin F 2000 Eur. J. Med. Chem. 35(9) 827

12. Filloux N and Galy J P 2001 Synlett 71137

13. Antonini I, Polucci P, Magnano A, Cacciamani D, Konieczny M T, Lukowicz J P and Martelli S 2003 Bioorg. Med. Chem. 11399

14. Bonacorso H G, Drekener R L, Rodrigues I R, Vezzosi R P, Costa M B, Martins M A P and Zanatta N 2005 J. Flu. Chem. 1261384

15. Xia J J and Zhang K H 2012 Molecules 175339

16. Venkatesan K, Pujari S S and Srinivasan V K 2009 Synth. Commun. 39228

17. Nikpassand M, Mamaghani M and Tabatabaein K 2009 Molecules 141468

18. Rashedian F, Saberi D and Niknam K 2010 J. Chin. Chem. Soc. 571006

19. Li Y L, Zhang M M, Wang X S, Shi D Q, Tu S J, Wei X Y and Zong Z M 2005 J. Chem. Res. Synop. 600

20. Tu S J, Miao C B, Gao Y, Feng Y J and Feng J C 2002 Chin. J. Org. Chem. 20703

21. Welton T 1999 Chem. Rev. 992083

22. Wasserscheid P and Keim W 2000 Angew. Chem. Int. Ed. 393773

23. Earle M J, McCormac P B and Seddon K R 1998 Chem. Commun. 202245

24. Liu F, Abrams M B, Baker R T and Tumas W 2001 Chem. Commun. 5434

25. Bates E D, Mayton R D, Ntai I and Davis J H 2002 J. Am. Chem. Soc. 124927

26. Kaur B, Parmar A and Kumar H 2011 Heter. Lett. 159

27. Kaur B, Parmar A and Kumar H 2012 Synth. Commun. 42453

28. Puri S, Kaur B, Parmar A and Kumar H 2009 Hetero. Commun. 1557 